\title{
RE-THINKING ATONEMENT IN JONATHAN EDWARDS AND NEW ENGLAND THEOLOGY
}

\author{
S. MARK HAMILTON* \\ Vrije Universiteit Amsterdam
}

\begin{abstract}
Jonathan Edwards' New England theology has a great deal more to say that is of contemporary doctrinal interest than it is often credited with, particularly as it relates to the doctrine of atonement. This article explores several anomalous claims made be this 18 th and 19th century tradition, and in this way, challenges the recent and growing consensus that Edwards espoused the penal substitution model and his successors a moral government model. I argue that of all that is yet to be considered about their doctrine of atonement, we ought to begin with those claims made about the nature and demands of divine justice.
\end{abstract}

KEY WORDS: Jonathan Edwards, New England Theology, Atonement, Divine Justice

\section{Introduction}

The doctrine of atonement in Jonathan Edwards and his successors has been the source of some recent and renewed interest. Until recently, the majority of interpreters had characterized Edwards' doctrine as on the one hand, 'Anselmian' by which is generally understood that Edwards subscribed to the doctrine of the absolute necessity of the atonement rather than what we might think of as full-orbed satisfaction model (Brown 2004: ch. 13). The absolute necessity of the atonement is the idea that the death of Christ was not merely the most 'fitting' way to make satisfaction for sin (as in the case of so-called hypothetical necessity), it was the only way to make satisfaction for sin (Heppe 1950: 469ff). These interpreters have also longdescribed Edwards' commitment to some sort of Grotian 'Moral Government' model of atonement-a full-orbed governmental model being commonly attributed to his successors. On this model, Christ performs the work of a penal example - his death restoring honor to the moral order by displaying the severity of sin's consequences for transgressions against the moral 
law (McDermott 2000: 42, n. 20). Now, more recent interpreters have argued all to the contrary, that Edwards articulated something closer to a version of the 'Penal Substitution' model of atonement while his successors articulated what has recently been re-branded as the 'Penal non-Substitution' model (Hamilton 2015: 1-22; Crisp 2012: 78-90). On the penal substitution model, Christ assumes the legal responsibility of the $\sin (\mathrm{s})$ of human persons and by his substitutionary death, pays their debt of punishment demanded by God's retributive justice. Penal non-substitution on the other hand better describes the New England version of the moral government model, with a theological premium put on the so-called 'suitable equivalence' of Christ's penal work. These most recent interpretive developments represent a tectonic shift, as it were, in our understanding about Edwards' thinking about the atonement and its development amongst those of his intellectual tradition; a shift that has since given rise to several important and yet unresolved questions about both the exact shape of New England theology's doctrine of atonement and more specifically, the findings of Edwards' earlier interpreters.

Among the more pressing and to my mind unresolved questions about Edwards and his tradition has to do with the how one cashes out the peculiar demands of divine justice and the specific judicial problem that the Edwardsian model of atonement was intended to solve. In this paper, I argue that Edwards and his successors both fail to adequately distinguish between the rectoral and retributive demands of divine justice and how Christ's work stands to meet those demands. For this reason, I think we have yet to arrive at a coherent picture of the doctrine of atonement in New England theology, and we won't, save for some constructive theological solution.

To this end, I consider what it means for Edwards to endorse the penal substitution model, in parallel with a sample of several curious statements that he makes about the demands of God's rectoral justice which appear to be in tension with those statements that he makes about demands of God's retributive justice - a notion that is at the heart of penal substitution. For the sake of clarity and brevity, I shall look at three aspects of the penal substitution model: (1) Representationalism, (2) Debts of Punishment, and (3) the nature of Divine Retribution, from a variety of Edwards' literature.

Since the latter two are at the fore of my concern, I will examine these aspects of the doctrine together. This will set up a discussion of several more curious statements about the atonement made by a second and then a third generation Edwardsian, namely, Jonathan Edwards Jr and Moses Stuart. These statements will show that the penal substitution model-a model often said to be supplanted by later Edwardsians-has some purchase on the thinking of both Edwards Jr and Stuart, the presence of which introduces an additionally complicating wrinkle in our attempt to bring some interpre- 
tative clarity to the doctrinal development of the New England theological tradition. I conclude with a constructive sketch of a model of atonement that attempts to make sense of these seemingly disparate aspects of Edwards' and his successors thinking about the work of Christ. Let us begin by turning our attention briefly to Edwards' Representationalism.

\section{Edwards and Representationalism}

Proponents of penal substitution often assume the truth of what is referred to as representationalism, which is the idea that God 'fixes', as it were, the relationship of persons, one to another (and to Christ), in such a way that the act of one person may be treated as if it is executed by another (or group of persons), irrespective of either the time or space at which the representative person performs the act or whether that act be morally good or bad (Shedd 2003: 451-55). Representationalism is, of course, one of the hallmarks of the Reformed theological tradition, to which appear several clear ascriptions throughout Edwards' work. For instance, he says,

What I think we may rationally and truly suppose concerning this matter, is this: that as of old God was long preparing his church to receive the doctrine of an atonement for sin by the sufferings of Jesus Christ, the second Adam, and imputing his sufferings to the sinner as one that in that matter stood for the sinner and was his representative, by representing himself as appeased and pardoning the sinner on the account of the sacrifices and vicarious sufferings and death of brute animals, and so long using his church and accustoming the world of mankind to the notion of an atonement by vicarious sufferings (Edwards 1993, 11: 307, 312).

Now, for Edwards' part-and this is what makes him unique amongst his Reformed brethren-he would have said something like, representationalism works if and only if we think of the representative and the ones represented as united beyond a bare legal (or federal) relationship, in some exotic way, where the ones represented (collectively) are the representative in some real (specifically, some Augustinian real) sense. This is quite an interesting discussion that has recently developed in Edwards studies. I mention it here only because it is material to Edwards' notion of representationalism, even though it is not necessarily material to what I argue here. For more on Edwards' version of representationalism, I direct my readers elsewhere (Hamilton 2013: 394-415; Crisp 2003: 308-327). So, moving forward with this aspect of penal substitution in mind, and its being a unique and firm fixture in Edwards' atonement formula, let us turn our attention to what Edwards says about the so-called debts of punishment demanded by God's retributive justice. 


\section{On Debts of Punishment and Retribution}

Something for which penal substitution invites some of its greatest criticisms is the idea that Christ's death is equivalent to his absorbing the penalty for the sin of humanity (usually understood to mean some number less than the total number of human persons; penal substitution is in principle consistent with universalism). To put it differently, the work of Christ is a payment of humanity's debt of punishment. This is quite a subtle and nevertheless critically important distinction from Christ's work being construed as payment for a debt simpliciter. Not understanding the difference between the nature of a simple debt and a debt of punishment is to miss the very essence of the penal substitution model altogether. And the difference is this: to owe God a debt of punishment is to owe a debt specifically for an offence that requires humanity (the debtor) suffer loss by suffering a punishment equivalent to their offense(s) (Lewis 2009: 329 [emphasis added]).

This is the work of Christ on the penal substitution model, namely, to suffer loss by paying humanity's debt of punishment to God's retributive justice. To owe God a debt of any other sort is to owe God for something that requires that God (the creditor) not suffer loss. The work of Christ in this light fits more than one model of atonement. And it is in this distinctionbetween debts and debts of punishment-where the tension in Edwards' account of divine justice and atonement appears. This tension has two parts. The first tension we will see by way of a contrast between what a debt demands and what a debt of punishment demands and we will see the second by understanding what we might call the direction, as it were, of sins offense.

\section{Edwards on Debts and Debts of Punishment}

First, notice that a debt of punishment requires that transgressors (or more accurately, Christ) suffer loss. In this way, the penal substitution model is surprisingly anthropocentric in terms of its chief goal, in that the problem facing sinners is not a matter of their failed effort to restore anything to God, so much as it is with his exacting a penalty from them (or again, Christ). Edwards says as much about this sort of judicial demand in several places throughout his work. For example, he argues that,

God declares that those sinners that are not forgiven shall pay the uttermost farthing, and the last mite, and that all the debt [of punishment] shall be exacted of them, etc. Now it seems unreasonable to suppose that God, in case of a surety, and his insisting on an atonement made by him, that he will show mercy by releasing the surety without a full atonement, anymore than that he will release it to the sinner that is punished, by not insisting on the complete punishment (Edwards 2002: 20: 460). 
In other words, in the same way that the full punitive demands of God's retributive justice are to be exacted from sinners, Edwards says that they are exacted from Christ and this, because he is their representative and God should require no less from him despite his status as a divine person (Levering 2015: 134-40). [Matthew Levering offers a recent and helpful synthesis of Edwards' thinking about punitive nature of divine justice and its relationship to both spiritual and somatic death, lending considerable strength to the idea that Edwards did in fact support some version of penal substitution. It is worth noting that several of his references to the nature of human suffering (and God's providential role in that suffering), however, might well be read in support of a penal non-substitution or moral government model.] Notice that Edwards says nothing in this context of what Christ's work does positively, that is, positively for God. This is because restoring anything to God is not a problem that the penal substitution model endeavors to solve.

Interestingly, in another place, Edwards argues that restoring to God the honor that is due the excellency of his being is precisely the work Christ undertook in making atonement. The following statement stands in contrast to Edwards' previous statement. He says,

The sacrifice of Christ is a sweet savor, [first], because as such it was a great honor done to God's majesty, holiness and law, and a glorious expression and testimony of Christ's respect to that majesty etc.; that when he loved man and so greatly desired his salvation, he had yet so great respect to that majesty and holiness of God, that he had rather die than that salvation should be any injury or dishonor unto those attributes. And then secondly, it was a sweet savor, as it was a marvelous act of obedience, and so an expression of a wonderful respect to God's authority. The value of Christ's sacrifice was infinite, both as a propitiation and as an act of obedience; because he showed an infinite regard to the majesty, holiness, etc. of God, in being at infinite expense from regard to it. (Edwards 1994: 13: 497 [emphasis added]).

To make the distinction between owing a debt and a debt of punishment clear, consider the following analogy.

Imagine that you get a call one day from 'Easy Eddy', the notorious Chicago gangster Al Capone's bookkeeper. Eddy calls to talk to you about some massive unpaid debt that you owe Capone after losing a few hands of poker to Capone a few weeks ago (Eig 2011). Eddy reminds you that you owe Capone a hundred-grand and that if you don't pay up soon, the next call you'll be getting will be a 'house call', from none other than Capone's socalled 'Enforcer', Frank Nitti, and a few of his leg-breakers-only they won't be breaking legs, they will be coming to finish you. Desperate to avoid a thrashing by Nitti-and-company, you quickly hang up on Eddy and phone your brother, Jake 'Greasy Thumb' Guzik, who happens to be a close- 
confidante of the Capone family. After telling your brother what you've done and that you don't have the money, he arranges a meeting with you and Capone to make a deal. To your great surprise and relief, in the meeting, your brother promises to pony-up the hundred-grand to pay your debt to Capone. The problem, however, is that having brokered the deal and bought your debt to Capone, your brother Guzik is now out a hundredgrand (provided he pays-up of course). What is interesting is that by discharging you of your debt to Capone, and assuming it himself, Guzik is now in a position to either forgive your debt to him outright and absorb the financial loss or exact the same sort of retribution from you, as would have Capone and company. Buying up your debt gives him that right. In this way, Guzik can either pay your debt or your debt of punishment.

Now, if we stop here we could cash out this analogy in terms of either a payment of a debt of punishment or payment of a debt. To owe Capone a debt - in this case, a debt of honor-means that he may neither lose money nor his honor and thus remains both vigilant and patient until these things are restored to him. To owe him a debt of punishment means that getting back the money means less to Capone than killing you, perhaps in order to show that he is not one to be trifled with and that he will inevitably and eventually settle all accounts of those offenses against him. [I am conscious that this later arrangement could lend equal support to a moral government model of atonement in the sense-following our analogy-that Capone appears interested in little more than making a penal example of you. It seems to me that introducing the idea of substitutionary atonement is the razor's edge of difference between the moral government and penal substitution models. That Christ is punished for sin is the point. The reason for his punishment is the distinguishing factor and something controlled in large part by the particular designs of divine justice.]

It is the Capone-like exaction of a debt of punishment that is helps us understand the problem that the death of Christ solves on the penal substitution model. God's punitive action for offenses against him is the actualization of his retributive justice. And according to exponents of penal substitution, it is the retributive demands of divine justice that Christ takes upon himself to meet for humanity's sake. Divine retributive justice is simply (and awefully!) that which God visits upon the unrighteous for sins against him.

For Edwards' part, Christ is somehow depicted as paying both a debt simpliciter and a debt of punishment. For Christ to perform both of these works is, it seems to me, a problem on several levels. But before I show how this is a problem, let us consider a second aspect of a debt of punishment. 


\section{Edwards on Retribution and the Direction of Sins Offense}

The second aspect of a debt of punishment that demands our attention here is the underlying assumption that sins offense is directed against God himself, and not, say, against his moral law. According to Edwards,

Sin is of such a nature that it wishes ill, and aims at ill, to God and men, but to God especially. It strikes at God; it would, if it could, procure his misery and death. It is but suitable that with what measure it meets, it should be measured to it again. 'Tis but suitable that men should reap what they sow, and that the reward of every man's hands should be given him (Edwards 2000, 18:436).

In this way, exponents of penal substitution make much of the fact that divine retribution for offenses against God are private legal affairs-that is, they are offenses against God himself by individual, morally responsible creatures, in contrast to say, a public offense, which is an offense against a society. Consider that if someone commits a crime against another, that person is liable for the offense and punishment will likely befall the offending party. The individual who sins against God, so they argue, is thus justly liable to the punitive measures of God's retributive justice as an individual. Such exponents also make much of the fact that private or individual offenses require individual reconciliation. This is, so they claim, what Christ does in making atonement, namely, effect personal, individual, and legal reconciliation between persons and God. That sins offense is against God and that it is something with individual implications is evident from the previous quotations. However, Edwards says elsewhere that,

'tis requisite that sin should be punished, as punishment is deserved and just, therefore the justice of God obliges him to punish sin: for it belongs to God as the supreme Rector of the universality of things, to maintain order and decorum in his kingdom, and to see to it that decency and right takes place at all times, and in all cases. That perfection of his nature whereby he is disposed to this, is his justice; and therefore, his justice naturally disposes him to punish sin as it deserves. The holiness of God, which is the infinite opposition of his nature to sin, naturally and necessarily disposes him to punish sin (Edwards 2000: 18:437 [emphasis added]).

He then goes on to argue that,

God is to be considered in this affair not merely as the governor of the world of creatures, to order things between one creature and another, but as the supreme regulator or Rector of the universality of things, the orderer of things relating to the whole compass of existence, including himself, to maintain the rights of the whole, and decorum through the whole, and to maintain his own rights, and the due honor of his own perfections, as well as to keep justice among creatures. 'Tis fit that there should be one that has this office, and the office properly belongs to the supreme being. And if he should fail of doing justice to him [self] in a needed vindication of his 
own majesty and glory, it would be an immensely greater failure of his rectoral justice than if he should deprive the creatures, that are beings of infinitely less consequence, of their rights (Edwards 2000: 18:440 [emphasis added]).

A close reading of these two statements alongside the previous one reveal that these statements are actually incongruent. The problem here is that if penal offenses are both criminal and punishable, they are not, strictly speaking, private or individual, so much as public or societal affairs that are punishable by the authority of a system of laws, not an individual lawmaker. In other words, a coherent picture of penal substitution seems to require that sins offense be leveled against the moral law and not God himself, and that this a problem facing all persons collectively, not as individuals, as it is so often thought to be the case. For Edwards' part, he seems to conflate the two.

It might be helpful to think of the difference between the offenses that are tried in a United States district or civil court versus those tried in a United States criminal court. In a district court, someone might be sued, for example, for a breach of contract. Strictly speaking, this is not a criminal offense. This is a personal, (and therefore private) offense-one person versus another (even another individual group, as in a class action suit) - that is resolved by the offending party restoring or making reparation for the offended party. Criminal courts, by contrast, try criminal offenders. If someone is on trial for murder, say, that person's offense is, again, strictly speaking, not against the one they killed (though I am sure we would all agree that murder is, if not the most, among the most egregious personal offenses that human persons can perpetrate against one another). Rather, their offense is against the laws of the society to which both parties have presumably assented and which demand that murderers pay a debt of punishment to society upon the commitment of such a crime. And in the United States judicial system, this debt is paid by incarceration or in some states, death. In this way, murder, or any such criminal offense, is a public matter between the murderer and the society at large, not the murderer and the one that was murdered. To put it differently, and recalling out analogy, there's a difference between offenses against Capone himself and those levelled against the rules of his club.

Now, carrying this line of thinking over to the more recent suggestions of Edwards subscription to penal substitution, if Christ is said to pay a debt of punishment on behalf of others, then, the debt is actually not a private offense against God-like in a district court-requiring that something be restored (via reparation) to God, despite those claims of his being the privately offended party. (I suppose, were one to construe the three-ness of God in terms of a 'society' of persons in the God-head, as well as construe human persons as some sort of collective 'moral whole', in addition to their 
being morally responsible individuals, then it would be consistent to think of sin as a public offense that issues in a debt of punishment owed by a society. I am not conscious of any such theological argument having been made). So, to put it rather bluntly, nothing is restored to God on the penal substitution model. Instead, and quite to the contrary of the apparent demands of God's retributive justice, penal substitution seems only to make provision for God to restore righteousness to humanity, leaving God dishonored and his Son, crushed (as the prophet Isaiah says) for this dishonor, and what is more, all of this being of no apparent benefit to himself. And this is in contrast to Edwards' apparent thinking that the work Christ does in making atonement restores honor to God-something that belongs to owing and paying a debt of honor. The problem, as I have suggested before, is that Christ cannot perform both works. He cannot suffer as a penal substitute and a non-penal substitute. So, the question for us then is whether Edwards' commitment to the rectoral demands of divine justice are at odds with his commitment to the role of retributive justice issued by penal substitution. My answer is yes, they are at odds, and they are in no less than two important ways.

First, because Edwards construes sin as both a private offense against God for which humanity is liable to pay a debt of honor and as a private offense against God for which humanity is liable to pay a debt of punishment (which as we have seen previously is itself something of a contradiction, that is, if we understand a debt of punishment to be a public or societal offense)—both acts of which cannot be done simultaneously by a penal and non-penal substitute. In other words, Christ cannot absorb divine wrath for sin as a penal substitute, when he is at the same time (collectively) deferring or delaying that wrath until the consummation by making reparations on behalf of all humanity.

The second way they are at odds, is because Edwards construes the nature of Christ's substitutionary work in what we might call 'personal' and then 'meritorious' terms. By personal substitution, I mean the substitutionary work he performs by 'standing in', as it were, for individual persons upon whom are the retributive demands of God justice. By meritorious substitution, I mean the substitutionary work he performs by accumulating the reparative merit of honor that offsets the infinite demerit of sin. For, because God is infinitely holy, sins against God accrue an infinite demerit, as it were, that requires some infinite merit to offset. It seems to me that, at least with respect to the mechanism of the atonement, these are not complimentary accounts of substitution so much as competing ones. For no honor is restored to God by his meeting out retribution against the Son on the cross-paying a debt of punishment does not necessarily pay a debt of honor. 
So, in these two ways at least, there is a tension in Edwards' account of Christ's atoning work. The question that remains is this: where do we go from here?

Like previous interpreters of Edwards-ones that I have elsewhere criticized for doing what I suggest we now do-let us look at the atonement formula of his successors in order to see what light (if any) might be shed upon this tension in Edwards account of Christ's work. Before we proceed, it must be said that reading those of a particular theological tradition back on to their theological patriarch-like Calvin and the Calvinists or Arminius and the Arminianians_ — can be perilously misleading.

In order to avoid the risk of gross inaccuracies by anachronism, I set out several statements from both Edwards Jr and Stuart, specifically related to the nature of divine justice and what I think is a matter of either category confusion or some theological nuance that has been lost on modern readers of the tradition. I've chosen Edwards Jr because of the recent attention paid to him in the literature. I've chosen Stuart because he is sadly overlooked by most contemporary scholars - an all too common plight if you were ever a part of the Edwardsian ilk-and because his Two Discourses on the Atonement showcase in a more systematic theological way, the sort of categorical confusion and oddities I am try to illumine. Let us begin with Edwards Jr.

\section{Atonement and Divine Justice in New England Theology}

The son of the Northampton Sage, Dr Jonathan Edwards Jr. contributed a great deal more to the development of the New England Theological tradition than he is often credited with (Ferm 1976). Of the variety of theological writings that offer some additionally detailed insight into the development of his father's legacy regarding the atonement, there are two works in particular that shed some help light on Edwards Jr.'s thoughts about the work of Christ. The first is his Thoughts on the Atonement, echoes of which appear in the second piece called Remarks on the Improvements Made in Theology by His Father, President Edwards. In both cases, the younger Edwards makes a number curious statements that point in the direction of his ascent to something along the lines a penal substitution model atonement. What is interestingwhat makes this evidence so curious-is that Edwards Jr has never been attributed with articulating anything but a so-called penal non-substitution model of atonement, where (roughly) the work Christ accomplishes is claimed to be that of a penal example-repairing the dishonor done to the moral law by humanity's transgression(s) against it. Consider the following two statements, each one representing a sort of core sample of ideas in which are resident both Dr Edwards' clear out-working of the penal nonsubstitution model and the presence of substitutionary language in keeping with his father. Dr Edwards writes, 
By atonement, I mean something done or suffered, which, to the purpose of supporting the honor and dignity of the divine law and government, shall be equivalent to the punishment of the sinner according to law. Therefore, the atonement made by Christ implies his substitution in the stead of the sinner, who is to be saved by him; or that he suffered that in the sinner's stead, which as effectually tended to discourage, or prevent transgression, and excite to obedience, as the punishment of the transgressor himself, according to the letter of the law would have done (Edwards Jr 1842).

In another place, he maintains that

The atonement is the substitute for the punishment threatened in the law; and was designed to answer the same ends of supporting the authority of the law, the dignity of the divine moral government, and the consistency of the divine conduct in legislation and execution. By the atonement, it appears that God is determined that his law shall be supported; that it shall not be despised or transgressed with impunity; and that it is an evil and a bitter thing to sin against God. The very idea of an atonement or satisfaction for sin, is something which, to the purposes of supporting the authority of the divine law, the dignity and consistency of the divine government, is equivalent to the punishment of the sinner, according to the literal threatening of the law. (Edwards Jr 1842: 8-9).

Clearly, from these statements, the idea of substitutionary atonement is part of the way Edwards Jr thought about Christ's work. Whether we can call this a full-blown doctrine of penal substitution remains to be seen, and is admittedly, a stretch. What these statements confirm at least, however, is that Edwards Jr did not necessarily expunge all substitutionary components from his thinking about the atonement. What precisely was substituted is the question. Before we consider an answer and attempt to reconcile these disparate statements, let us first turn our attention to Stuart for what I think is some additional clarity.

Moses Stuart is one of the most important and strangely most underappreciated nineteenth-century New England theologians. Hailed 'the father of biblical science in America', Stuart's literary output is nothing short of astonishing, publishing Hebrew, Greek and Semitic language grammars, biblical commentaries-Old and New Testament alike, translations of various Latin and German texts, critical biographies, essays on various (and some controversial) theological subjects, as well as collections of sermons, treatises, and pamphlets on Christian practice (Giltner 1988). Of interest to our general inquiry and to our making theological sense of Edwards Jr's anamolous statements are two sets of comments that Stuart makes about the work of Christ as it relates to divine justice in his Two Discourses on the Atonement (Stuart 1828: 1-46). For, much like Edwards Jr, one set of texts seems 
to make clear Stuart's purchase upon something like the penal substitution model. Another set, again much like Edwards Jr, seems to point toward a penal non-substitution model. The difference here, however, is that Stuart's seemingly contradictory claims are far more explicit.

Stuart begins his Two Discourses with an analytic series of definitions, which is where we first find evidence for his articulation of something like a penal substitution model. At the outset, he explains that

To proceed with the explanation proposed under the present head, when I say 'Christ in his sufferings was our substitute, or, by them he made an expiation offering for us', I mean that God did appoint and accept the sufferings of Christ, instead of the punishment due to us as sinners against the law; and that in consequence of this appointment and of these sufferings, he does forgive our sins and receive us to his favour (Stuart 1828: 7 [emphasis added]).

Here Stuart describes this substitutionary work in terms of Christ's making what he calls an 'expiation offering', which, as he continues, 'under the Jewish law, was a slain beast, presented to God by his appointment, and by a person who had been guilty of some offense and incurred a penalty'. Building off a strong typological reading of Scripture throughout his treatise, Stuart goes on to say that 'Christ made an expiation offering for us, according to my apprehension of the meaning of Scriptural language, implies his suffered and death were, by divine appointment, accepted instead of the punishment due to us, sinners, and that God, in consequence of the offering made by Christ, pardons out offenses and restores us to his favour' (Stuart 1828: 7). This sounds much like Edwards Jr's consistent appeal to the 'suitable equivalence' of Christ's sacrifice (Crisp 2008: 140-168). Interestingly, after taking pains to define and classify the model of atonement he sets out to defend-something he picks up again with greater detail in the subsequent section-Stuart makes the following (and as we shall see, rather curious) appeal to his readers, and here I quote him at length.

I do not feel at all disposed to find fault with other language, which Christians may choose to employ, in order to designate the idea that I have now expressed, provided they define the sense in which they employ it, and do not leave it open to misconstruction. So doing they may say, 'Christ made satisfaction for our sins;' or, 'his death was a full equivalent for the demands of the law;' or, 'our punishment-our guilt—was transferred to him.' I may also say, 'Christ made a atonement-Christ atoned-for our sins; his sufferings were vicarious-were in lieu of ours; he bore the punishment due to us.' In reality, can such contention amount to anything more than a strife about words? A strife unworthy of sober and earnest inquirers after truth; and one which never can serve any purpose, but to alienate from each other and divine those, who love the Saviour, and trust for acceptance with God solely in his atoning blood (Stuart 1828: 8-9). 
With this rather awkward attempt at disambiguation, Stuart turns his attention to several more distinctions that push in quite the opposite direction of any sort of penal substitution model. For example, he writes,

Indeed, I view the great object of the divine law, as answered by the death of Christ in a much higher degree than it could have been by a mere lawadministration, and a literal infliction of the penalty. Must now his death be regarded as a more awful manifestation of divine displeasure against sin, than the execution of the law on sinners themselves? If [philosophers] present the death of Christ as a most awful and affecting display of the evil of sin, and of the divine displeasure against it, enhanced beyond description by the dignity of his person, and the peculiar severity of his sufferings; and if this makes an appeal to the moral sensibilities of the human race, in favour of gratitude and obedience to God, and against sin, in a manner far more affecting and successful, than the literal execution of the penalty of the law on sinners; is not this sufficient? (Stuart 1828: 14).

As with Edwards Jr, we are left wondering just what Stuart actually thought about the atonement, and specifically, how substitution plays into a nonsubstitutionary model of Christ's work. It seems to me there are (at least) three possible answers. Consider that both the good Doctor Edwards and Stuart were simply unconscious of the impact of the commitment they were making by trotting out such a claim-a case of category confusion, perhaps. Given Stuart's attempt to make his commitments plain, this first possibility seems highly unlikely. I think they both knew exactly what they were intending. If I am correct, then perhaps they saw a theological way forwarda way that makes the New England model of penal non-substiitution unique to the rest of the moral government tradition - that we have yet to discover. In other words, perhaps they found a way that Christ can be both a substitute and a non-substitute that avoids the obvious logical contradiction. If such a possibility is in fact the case, then it has yet to be developed by contemporary scholars.

The most likely possibility, I think, has to do with how Edwards Jr and Stuart construe of the nature of substitution. Notice that neither of them say anything about Christ being a substitute for individuals. Notice also their emphasis on Christ's substitutionary work as having a direct impact on the demands of the moral law, which, as we saw in the case of President Edwards is a public or societal matter-humanities offence is against the moral law, not God, strictly speaking. By implication, it looks like the solution (atonement) to the problem (transgression of the moral law) effects all humanity. How can this be? The answer, I think that the good doctor may well have augmented individual substitutionary atonement to some account of universal substitutionary atonement, in keeping with Oliver Crisp's relative- 
ly recent suggestion that we ought to understand two things about the Edwardsian tradition.

First, that the New England theologians were interested in doctrinal development and ought to be seen in this light (rather than some sort of doctrinal decline and fall, as has been the earlier trend). Second, that their developments as they relate to the atonement tended toward expressions of some sort of hypothetical universalism, according to which Christ's work extends in some sense to all persons-like we see here Edwards Jr and Stuart. Taking one explanatory step further than Crisp, it looks like Edwards Jr and Stuart have perfectly legitimate (however awkward) reasons to speak about penal substitution in the context of Christ's non-substitutionary act, provided we understand that by penal substitution they mean that Christ's work solved a moral-law specific legal problem for everyone.

It is interesting for our understanding of Edwards Sr that his successors say so much of the rectoral demands of the moral law and so little, if anything, of the rectoral demands of God himself. This is perhaps telling about how we make sense of anomalous appearance of both substitutionary language, moral government language, and the oddities of Edwards' account of rectoral and retributive justice. By way of conclusion, let me suggest the following.

\section{Conclusion: A Way Forward?}

I tried to make the case that there is a great deal more work to be done on Edwards' doctrine of atonement. I am no longer convinced that we can make definitive claims about his adherence to the penal substitution model. That Edwards' commitments about retributive justice appear to stand in tension to his commitments about rectoral justice forces us to rethink our assurances about the model of atonement to which Edwards might have subscribed. It seems entirely possible to me at this point that the early interpretive tradition was on to something, but perhaps they might not have gone far enough in describing that Edwards held to some version of an Anselmian satisfaction model of atonement, according to which the Son dies in order to restore honor to the Father-sacrificing himself in an act of infinite merit - that is somehow, at the same time, able to make sense the penal aspects of the moral law associated with a moral government model of atonement and all this without making Christ absorb the penalty for sin, as in the case of a penal substitution model. While, arriving at any detailed structure of such a model is, of course, well beyond the scope of this paper, I want to suggest that the first constructive step of the model that I have in mind begins with making sense of the rectoral aspect of Edwards' doctrine of divine justice. 


\section{Bibliography}

Brown D (2004) Anselm on the Atonement. In Davies B, Leftow B (eds) The Cambridge Companion to Anselm. Cambridge: Cambridge University Press.

Crisp OD (2003) On the Theological Pedigree of Jonathan Edwards' Doctrine of Imputation. In Scottish Journal of Theology 56(3): 308-327.

Crisp OD (2008) Penal Non-Substitution. Journal of Theological Studies 59(1): $140-168$.

Crisp OD (2012) The Moral Government of God: Jonathan Edwards and Joseph Bellamy on the Atonement. In Crisp OD, Sweeney DA (eds) After Jonathan Edwards. The Course of New England Theology. New York, NY: Oxford University Press, pp. 78-90.

Edwards J (1957-2006) The Works of Jonathan Edwards in 26 volumes. Miller P, Smith JE, Stout HS (eds) New Haven, CT: Yale University Press.

Edwards Jr. J (1842) 'Remarks on the Improvements Made in Theology by His Father, President Edwards. In Edwards T (ed) Works of Jonathan Edwards D.D., Late President of Union College, volume 1. Andover, MA: Allen, Morrill, and Wardenwell.

Eig J (2011) Get Capone: The Secret Plot That Captured America's Most Wanted Gangster. New York, NY: Simon and Schuster.

Ferm RL (1976) Jonathan Edwards the Younger (1745-1801). A Colonial Pastor. Grand Rapids, MI: Eerdmans.

Giltner JH (1988) Moses Stuart. The Father of Biblical Science in America. Atlanta, GA: Scholars Press.

Hamilton SM (2013) Jonathan Edwards on the Atonement. International Journal of Systematic Theology 15(4): 394-415.

Hamilton SM (2015) Jonathan Edwards, Anselmic Satisfaction, and God's Moral Government. International Journal of Systematic Theology 17(1): 1-22. Heinrich H (1950) Reformed Dogmatics. London: HarperCollins.

Levering M (2015) Jonathan Edwards and Thomas Aquinas on Original Sin. In Strobel KC (ed) The Ecumenical Edwards. Jonathan Edwards and the Theologians. Aldershot: Ashgate.

Lewis D (2009) Do We Believe in Penal Substitution. In Crisp OD (ed) $A$ Reader in Contemporary Philosophical Theology. New York, NY: T \& T Clark.

McClymond MJ, McDermott GR (2011) The Theology of Jonathan Edwards. New York, NY: Oxford University Press.

McDermott G (2000) Jonathan Edwards Confronts the Gods. New York, NY: Oxford University Press.

Shedd WGT (2003) Dogmatic Theology. Phillipsburg, NJ: Presbyterian and Reformed.

Stuart M (1828) Two Discourses on the Atonement. Andover, MA: Flagg and Gould. 